Columbia Law School

Scholarship Archive

2013

\title{
Getting Ahead of the Curve: Supporting Adaptation to Long-term Climate Change and Short-term Climate Variability Alike
}

\author{
Alexis Saba \\ Columbia Law School \\ Michela Biasutti \\ Columbia University, biasutti@Ideo.columbia.edu \\ Michael B. Gerrard \\ Columbia Law School, michael.gerrard@law.columbia.edu \\ David B. Lobell \\ Stanford University
}

Follow this and additional works at: https://scholarship.law.columbia.edu/faculty_scholarship

Part of the Environmental Law Commons

\section{Recommended Citation}

Alexis Saba, Michela Biasutti, Michael B. Gerrard \& David B. Lobell, Getting Ahead of the Curve: Supporting Adaptation to Long-term Climate Change and Short-term Climate Variability Alike, 7 CCLR 3 (2013).

Available at: https://scholarship.law.columbia.edu/faculty_scholarship/563 


\title{
Getting Ahead of the Curve: Supporting Adaptation to Long-term Climate Change and Short-term Climate Variability Alike*
}

\author{
Alexis Saba, Michela Biasutti, Michael B. Gerrard, and David B. Lobell**
}

The United Nations Framework Convention on Climate Change (UNFCCC) has been meeting since 1995, and in recent years, it has increasingly focused on facilitating and funding climate change adaptation in developing countries. Other sources of financing, from multilateral development banks to bilateral and multilateral agreements among countries, are also providing resources for adaptation. Simultaneously, climate scientists around the world are updating their forecasts on the nature of future climate change. This article seeks to examine the scope of funding available for climate change adaptation and how climate change forecasts are used to plan for and evaluate climate change adaptation. We narrow our focus to sources and examples relevant for the African Sahel. After surveying recent UNFCCC negotiations, the financing frameworks of numerous funding sources, and an adaptation project in Ethiopia, we find that most adaptation projects in this region address vulnerabilities to current climate, without considering where climate change will bring new or increased risks. Therefore, today's adaptation projects, while effective in enhancing climate resilience in the short run, may well fail to adequately prepare the people of the Sahel for long-term climate change. Recognizing the need of many countries to cope with current climate variability as well as to prepare for future climate change, this paper concludes with recommendations for how climate adaptation funds could strike a better balance between the two in a way that helps the people of the Sahel and other developing countries get ahead of the curve and prepare for the emerging new climate.

* This project was financed by National Science Foundation Award SES 10-48946.

** Alexis Saba is a former postdoctoral fellow at Columbia Law School's Center for Climate Change Law; Michela Biasutti is an Associate Research Scientist at Columbia University's LamontDoherty Earth Observatory; Michael B. Gerrard is the Director of Columbia Law School's Center for Climate Change Law and is the corresponding author; and David Lobell is the Associate Director of Stanford University's Center for Food, Security and the Environment. Email: michael.gerrard@law.columbia.edu.

1 See generally United Nations Framework Convention on Climate Change, 9 May 1992, in force 21 March 1994, 1771 United Nations Treaty Series (1992), 107.

2 See Anna Petherick, "Enumerating Adaptation", 2 Nature Climate Change (2012), 228: "In 2010, adaptation accounted for just $8 \%$ of all approved climate finance; in 2011 that proportion rose to $21 \%{ }^{\prime \prime}$; Richard J.T. Klein et al., Adaptation: Needs, Financing and Institutions (Stockholm: SEI, 2008), 10: "Since the UNFCCC's entry into force in 1995 the main focus of climate policy has been on mitigation. This changed with the adoption of the Bali Action Plan in December 2007."

\section{Introduction}

Climate change mitigation, the moderation of temperature increases through reductions in emissions or emissions growth, ${ }^{1}$ remains the central component of global climate change action under the United Nations Framework Convention on Climate Change (UNFCCC). Nonetheless, climate change adaptation is playing an ever more prominent role at the UNFCCC annual meetings, the Conferences of the Parties (COPs), ${ }^{2}$ as exemplified by the creation of the Green Climate Fund in 2009 in Copenhagen with the goal of mobilizing $\$ 100$ billion per year by 2020 for climate change activities including adaptation. Many other entities are also financing adaptation, such as the World Bank's Strategic 
Climate Fund, to which $\$ 920$ million has been pledged. $^{3}$

Climate change is defined by the UNFCCC as "a change of climate which is attributed directly or indirectly to human activity that alters the composition of the global atmosphere and which is in addition to natural climate variability observed over comparable time periods." ${ }^{\prime 4}$ Although, by this definition, climate change is most easily detectable over the long term and at continental scales, it nonetheless will be expressed as changes in climate parameters at all time scales, from the character of weather events (e.g., more intense downpours) to that of interannual variability (e.g., more frequent hot summers), and will be experienced by necessity as a local phenomenon. For this reason, it has been argued that all adaptation to climate change must be local and must be adaptation to climate variability. ${ }^{5}$ However, this article argues that the incorporation of adaptation to climate variability into adaptation to climate change has been taken so far as to shortchange state-of-the-art climate change forecasts and adequate preparation for the predicted impacts of long-term climate change.

Drawing from recent UNFCCC negotiations, the financing frameworks of numerous funding sources, and an adaptation project in Ethiopia, this paper suggests that most recent adaptation projects address current climate risks, often with little consideration to growing risks brought about by climate change. Looking at the African Sahel specifically, we find that the projects and the programs that fund them are largely focused on adaptation to climate variability and on climate resilience. These projects emphasize adaptation to historic and current weather patterns and prioritize development planning and poverty-reduction goals in climate change adaptation. While this focus aids Sahelian countries in the near term, it likely will not fully prepare them for long-term climate change given the drastically different climate predicted for the future, especially regarding temperature and extreme rainfall intensity.

Part II of this paper draws on our own research and, more broadly, on both the original scientific literature and the IPCC reports to describe the difference between climate change and climate variability and why this difference matters to adaptation. Part III examines the scope of funding available for climate change adaptation in the African Sahel and how climate change forecasts are used to plan and evaluate climate change adaptation projects in this region. Part IV relays first-hand observations of climate change adaptation discussions from $\mathrm{COP} 16$ and $\mathrm{COP}_{17}$ and reviews the use of climate change forecasts in the development of an adaptation project in Ethiopia. Part V provides recommendations for how to better strike the balance between adaptation to climate change and climate variability in a way that helps the people of the Sahel and other developing countries get ahead of the curve and prepare for the new climate that will emerge in the coming decades.

\section{Climate Change versus Climate Variability}

While the scientific literature typically defines climate change in very broad terms, to include "any change in climate over time, whether due to natural variability or as a result of human activity, ${ }^{n 6}$ we follow the UNFCCC standard of referring to anthropogenic climate change in the industrial era and in the future simply as climate change, while we denote as climate variability what would be more properly called internal climate variability, that is "variations in the mean state and other statistics (such as standard deviations, the occurrence of extremes, etc.) of the climate on all temporal and spatial scales beyond that of individual weather events [...] due to natural internal processes within the climate." Future climate change, in this context,

\footnotetext{
3 Climate Investment Funds, "History", no date given, available on the Internet at <http://www.climateinvestmentfunds.org/cif/ designprocess> (last accessed on 25 July 2013).

4 UNFCCC, supra, note 2, at Art. 1, para. 2.

5 "The [IPCC] maintains very strongly that learning to deal with climate variability and extremes is an excellent way of building adaptive capacity in the long run." Least Developed Countries Expert Group, "Annotated Guidelines for the Preparation of National Adaptation Programmes of Action", July 2002, available on the Internet at <http://unfccc.int/files/cooperation_and_support/ Idc/application/pdf/annguide.pdf $>$ (last accessed on 25 July 2013). See also Edward S. Sarachik, "The Tools Needed to Provide Information for Adaptation to Future Climate Conditions", $2^{\text {nd }}$ International Conference: Climate, Sustainability and Development in Semi-Arid Regions, 16-20 August 2010, Fortaleza-Ceara, Brazil.

6 Martin L. Parry et al. (eds), Climate Change 2007: Impacts, Adaptation and Vulnerability (Cambridge: Cambridge University Press, 2007), at 871 (Contribution of Working Group II to the Fourth Assessment Report of the Intergovernmental Panel on Climate Change).

7 lbid. at 872 .
} 
is estimated to be the response of the climate system to anthropogenic emissions of particulate matter and, chiefly, greenhouse gases.

The predictions for man-made climate change vary considerably. This is due, among other factors, to (i) different sources of uncertainty associated with what the forcing will be (mainly, the future sources of pollution), (ii) the different estimates of the response provided by different computer models of the climate, and (iii) the difficulty of distinguishing, in simulations of the future, the natural vagaries of climate from the forced response. ${ }^{8}$ All these forms of uncertainty are exacerbated at smaller spatial scales and for aspects of the climate that depend strongly on the details of the terrain and on small-scale processes. This implies that climate change predictions are most trustworthy for quantities that vary smoothly over large areas, such as temperature and rainfall intensity, and less trustworthy for quantities that do not, such as rainfall accumulation (which is determined by rainfall frequency, instead of intensity). ${ }^{9}$

Predicting regional rainfall changes at tropical locations is especially prone to uncertainty because tropical rainfall is produced by bursts of convection unresolved by climate models and is sensitive to small-scale variations in soil moisture and topography. Accordingly, adaptation projects specifically addressing the anthropogenic component of rainfall trends would be very difficult to design for tropical locations, most of which are located in developing countries. As Part II describes, most current adaptation is nonetheless focused on rainfall changes.
One reason for this focus on rainfall changes is that the history of climate impacts in tropical regions is the history of rainfall variability: the famine that follows the failure of the monsoon, ${ }^{10}$ the desert that advances during decades of drought, ${ }^{11}$ the outbreak of meningitis in a dry and dusty year, ${ }^{12}$ just to give some examples. If past is prologue, it makes sense to focus adaptation on rainfall.

Moreover, the natural variability in rainfall at the local scale is so large in most tropical areas that, despite the projection of enhanced interannual variability in hydroclimate under global warming, ${ }^{13}$ model projections indicate with some confidence that the future distribution of rainfall anomalies will significantly overlap with the historical distribution. ${ }^{14}$ What this means is that, even if the mean rainfall over, say, the last decades of the $21^{\text {st }}$ Century will be significantly different from today's, most years will likely receive as much rainfall as some other year in the historical record, and only a few years will see unprecedented rainfall deficit or excess. ${ }^{15}$ (See Figure 1a for an example of simulated rainfall at a single grid point in the Sahel, in a single climate model, and in a single scenario for future emissions. In this example the projection is for mean drying and overall increase in variability, but these are by no means sure things; in fact, most other models suggest that rainfall might increase in the Sahel in this century. $)^{16}$ Again, in this context adaptation to rainfall variability can serve, to some degree, as a stand-in for adaptation to climate change, and full consideration of the climate change forecasts becomes less vital.
8 Susan Solomon et al. (eds), Climate Change 2007: The Physical Science Basis (Cambridge: Cambridge University Press, 2007), at ch. 10 (Contribution of Working Group I to the Fourth Assessment Report of the Intergovernmental Panel on Climate Change).

9 lbid.

10 See Mike Davis, Late Victorian Holocausts: El Niño Famines and the Making of the Third World (London: Verso, 2001).

11 See Sharon M. Herrmann and Charles F. Hutchinson, "The Changing Contexts of the Desertification Debate", 63 Journal of Arid Environments (2005), at 538-555; Alessandra Giannini et al., "A Climate Model-based Review of Drought in the Sahel: Desertification, the Re-greening and Climate Change", 64 Global and Planetary Change (2008), at 119-128.

12 See Working Group II, supra, note 7, at ch. 8; Benjamin Sultan et al., "Climate Drives the Meningitis Epidemics Onset in West Africa", 2 PloS Medicine (2005), at 43-49.
13 See R. Seager et al., “Does Global Warming Cause Intensified Interannual Hydroclimate Variability?", 25 journal of Climate (2012), at 3355-3372.

14 See B.R. Lintner et al., "Amplification of Wet and Dry Month Occurrence over Tropical Land Regions in Response to Global Warming", 117 Journal of Geophysical Research (2012), at D11106.

15 This is not necessarily true for regional anomalies, for which the climate change signal is bound to be a larger fraction of the natural variability. Moreover, some human and natural systems respond to the cumulative effect of repeated drought over several years, which might indeed be unprecedented.

16 See Michela Biasutti, "Forced Sahel Rainfall Trends in the CMIP5 Archive", 118 Journal of Ceophysical Research (2013), at 1613-1623. 
However, a growing body of research has highlighted that the extreme heat expected under anthropogenic climate change can have serious effects on agriculture in both the midlatitudes ${ }^{17}$ and the tropics. ${ }^{18}$ Interannual and interdecadal variability in temperature in the tropics has historically been small, so the impact of temperature variability on agriculture has been dwarfed by the impact of rainfall variability. However, unabated anthropogenic warming will lead to unprecedented temperature regimes. ${ }^{19}$ As an example, note the magnitude of year-to-year variability to the longterm change in temperature in Figure $1 b$, and compare it to the corresponding changes in rainfall in Figure 1a. (Note that while different models and scenarios might suggest a quantitatively different picture, this example is representative of a pattern seen across a wide range of simulations. ${ }^{20}$ Hot temperatures have the potential to strongly affect agricultural systems that are not adapted to such heat, by shortening crop duration, sterilizing reproductive organs, or aiding pests and disease vectors. For example, a recent study has shown that each day spent above $30^{\circ} \mathrm{C}$ can reduce maize yield by about $1 \% .{ }^{21}$ Therefore, with climate change, temperature has the potential to be a significant, or even dominant, control of agricultural productivity, even in areas where it has been relatively insignificant in the historical record.

Agricultural adaptation to climate change must include this added dimension, and while adaptation to climate variability as we know it is still very much necessary, it is not enough. This last point is well illustrated by Figure 2, which shows the sensitivity of maize yields to a warming of $1^{\circ} \mathrm{C}$ as a func- tion of the mean temperature at which the crops were growing and in two distinct cases: one in which the crops had plentiful water and one in which they were water-stressed. For growing-season temperatures above a threshold of about $24^{\circ} \mathrm{C}$ (for maize in South Africa), additional warming leads to a loss of yield - whether the crops have sufficient or insufficient water. This suggests that adaptation to increased heat is needed in all cases. At the same time, drought-stressed crops are more sensitive to heat (an additional $1^{\circ} \mathrm{C}$ warming leads to a reduction in yield in all cases, no matter what the mean growing-season temperature is), highlighting how drought management practices will continue to be essential.

Another source of risk that is forecast to increase is the intensity of extreme rainfall events. ${ }^{22}$ Heavy downpours are a well-known cause for destructive floods in urban areas, but they can also reduce agricultural yields by washing away valuable nutrients and soil. While the magnitude of the increase in extreme rainfall intensity suffers from significant uncertainty, the fact that intense rainfall will become a growing risk is not in doubt, as it is expected from theoretical arguments ${ }^{23}$ and is robustly simulated by climate models. ${ }^{24}$ Moreover, the expectation is that changes in extreme intensity will be similar across vast regions of the tropics. ${ }^{25}$

The growing importance of factors other than drought in hampering agriculture indicates a need for adaptation measures that are specific to the global warming problem and are implemented alongside adaptation to current climate variability. Now the climate forecast becomes both important and useful, as projections of unprecedented heat
17 See Wolfram Schlenker and Michael J. Roberts, "Nonlinear Temperature Effects Indicate Severe Damages to U.S. Crop Yields under Climate Change", 106 Proceedings of the National Academy of Sciences of the United States of Arnerica (2009), at 15594.

18 See W. Schlenker and David B. Lobell, "Robust Negative Impacts of Climate Change on African Agriculture", 5 Envtl. Research Letters (2010), at 1-8; David B. Lobell et al., "Nonlinear Heat Effects on African Maize as Evidenced by Historical Yield Trials", 1 Nature Climate Change (2011), at 42-45.

19 See David Battisti and Rosamond L. Naylor, "Historical Warnings of Future Food Insecurity with Unprecedented Seasonal Heat", 323 Science (2009), at 240; J. Sillmann et al., "Climate Extremes Indices in the CMIP5 Multimodel Ensemble: Part 2. Future Climate Projections", 118 Journal of Ceophysical ResearchAtmospheres (2013), at 2473-2493.
20 See Battisti, supra, note 20.

21 Lobell, supra, note 19.

22 Christopher B. Field et al. (eds), Managing the Risks of Extreme Events and Disasters to Advance Climate Change Adaptation (Cambridge: Cambridge University Press, 2012), at 582 (A Special Report of Working Groups I and II of the Intergovernmental Panel on Climate Change).

23 Kevin E. Trenberth et al., "The Changing Character of Precipitation", 84 Bulletin of the American Meteorological Society (2003), at 1205-1217.

24 Claudia Tebaldi et al., "Going to the Extremes", 79 Climatic Change (2006), at 185-211.

25 Viatcheslav V. Kharin et al., "Changes in Temperature and Precipitation Extremes in the CMIP5 Ensemble", 119 Climatic Change (2013), at 345-357. 
and extreme rainfall intensity are less uncertain (at least qualitatively) and less location-dependent than rainfall projections.

Part III of this paper will discuss the various international funding mechanisms for adaptation to climate change. It will become apparent that these mechanisms are aimed at climate variability and climate resilience, not as much at the growing risks from long-term temperature and extreme precipitation trends that have just been discussed.

\section{Figure 1:}

Top: Rainfall accumulation during the month of August for the period 1900-2099 as simulated by one climate model (CSIRO-Mk3-6-o, from the ensemble simulations run in preparation for the upcoming $5^{\mathrm{th}}$ assessment report of the Intergovernmental Panel on Climate Change) for a grid point in the Sahelian portion of Ethiopia $\left(40^{\circ} \mathrm{E}, 11^{\circ} \mathrm{N}\right)$. The bars are for individual months, and the horizontal lines are the averages for the $20^{\mathrm{th}}$ and $21^{\mathrm{st}}$ centuries. Note that this model projects a strong drying trend for the Sahel in the $21^{\text {st }}$ century, contrary to most other models. Units are in inches. The years from 1900 to 2005 are from a simulation forced with observed anthropogenic emissions; subsequent years are from a scenario simulation in which emissions of greenhouse gases follow a business as usual path (RCP8.5). A fuller explanation of the climate simulations is given by Taylor et al. (2012). ${ }^{26}$

Bottom: As in top, but for mean surface temperature in degrees Fahrenheit. Note that regional temperature increases tend to be larger when drought is also predicted; models that predict an increase in rainfall are likely to predict a more modest increase in temperature. The magnitude of the temperature increase is also a strong function of the model's climate sensitivity and the overall anthropogenic forcing (i.e., the cumulative emissions of well mixed greenhouse gases).

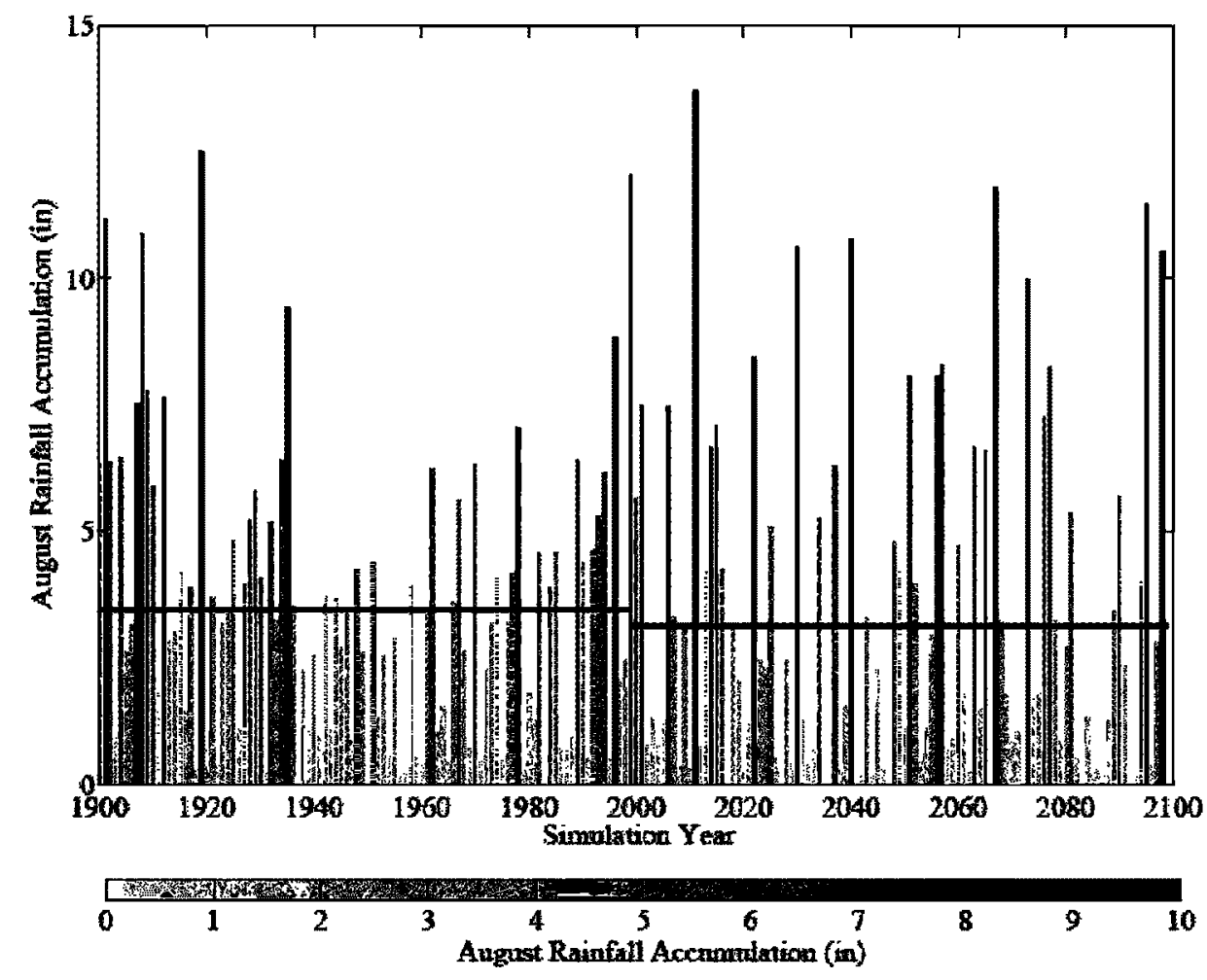

26 Karl E. Taylor et al., "An Overview of CMIP5 and the Experiment Design", 93 Bulletin of the American Meteorological Society (2012), at 485-498. 


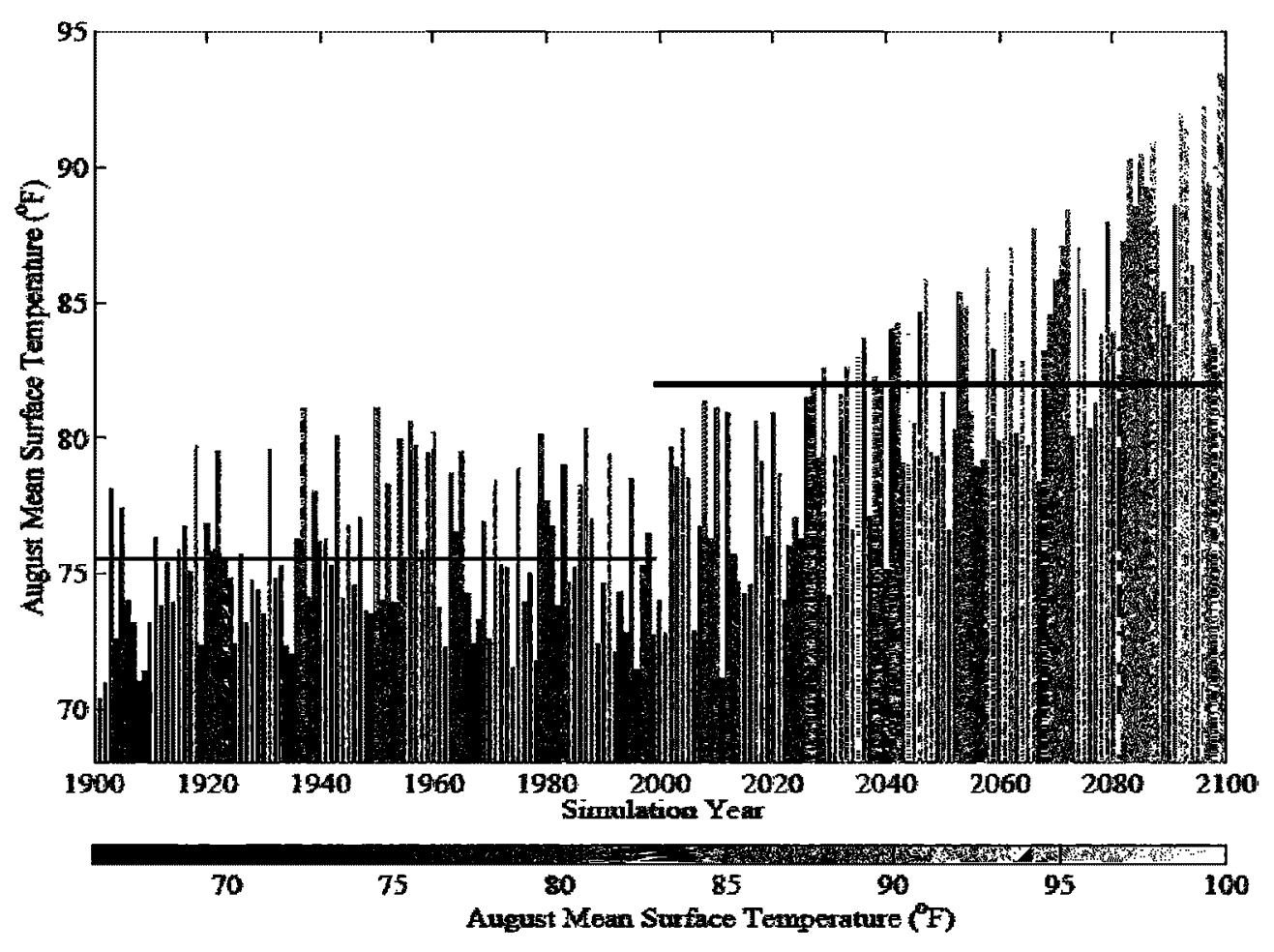

Figure 2: Adapted from Lobell et al. (2011). Model estimate of yield impact of $1^{\circ} \mathrm{C}$ warming for maize trials at different average growing-season temperatures, using regression equations for trials with optimal or drought management. The lines are the best fits to the mean impact at each temperature level, and the shaded areas show an estimate of the $95 \%$ confidence interval using robust standard errors.

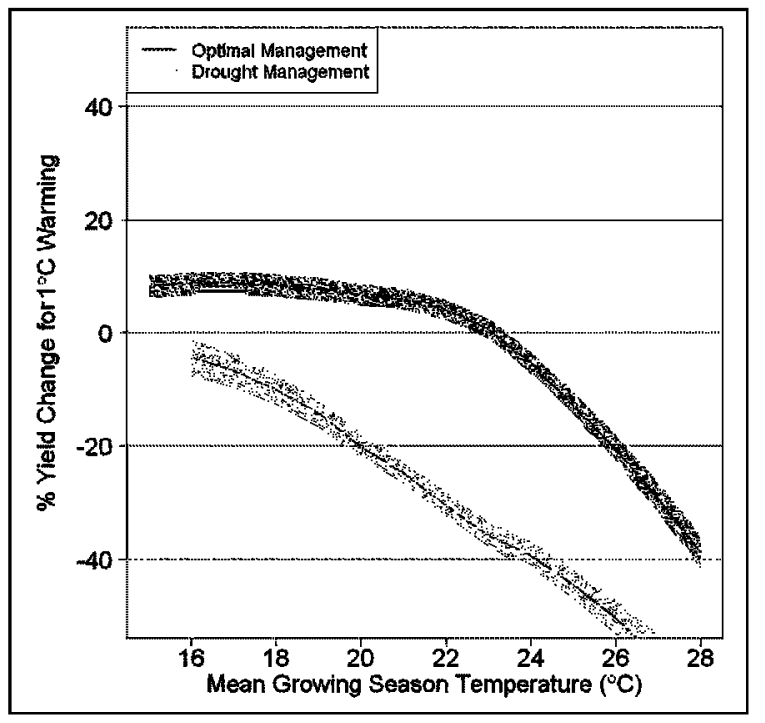

\section{Funding for Adaptation in the African Sahel}

There are numerous sources of funding for climate change adaptation projects in the African Sahel: UNFCCC funds, United Nations (UN) organizations, multilateral development banks (MDBs), and bilateral and multilateral arrangements among countries. The sections below discuss the scope of funding available and how climate change forecasts are used to plan and evaluate climate change adaptation projects.

\section{UNFCCC Funds}

The UNFCCC provides the basis for financial arrangements related to adaptation, ${ }^{27}$ and the COPs have expanded upon these arrangements and developed financing instruments. Four funds have traditionally financed climate change adaptation as well as the Green Climate Fund and fast-start financing program first adopted at $\mathrm{COP}_{15}$ in 2009 in Copenhagen. The funds are briefly described in the table below.

27 See UNFCCC, supra, note 1, at Arts. 4(1)(e), 4(3), 4(4), 4(8), $21(3)$. 


\begin{tabular}{|c|c|c|c|}
\hline Fund & Purpose & Money Allocated & Countries Eligible \\
\hline $\begin{array}{l}\text { Least } \\
\text { Developed } \\
\text { Countries } \\
\text { Fund (LDCF) }\end{array}$ & $\begin{array}{l}\text { - Support vulnerability and adaptation } \\
\text { needs assessments and the development } \\
\text { of National Adaptation Programmes of } \\
\text { Action (NAPAs) } \\
\text { - Supported by the Least Developed } \\
\text { Countries Expert Group (LEG), }{ }^{30} \text { which } \\
\text { also advises Least Developed Countries } \\
\text { (LDCs) on the preparation and imple- } \\
\text { mentation strategies for their NAPAs, } \\
\text { specifically regarding identification of } \\
\text { relevant data for vulnerability assess- } \\
\text { ments and of capacity-building needs }{ }^{31}\end{array}$ & $\begin{array}{l}\text { - About } \$ 217 \text { million for } \\
48 \text { NAPAs and } 52 \text { projects } \\
-33 \text { projects starting imple- } \\
\text { mentation } 32\end{array}$ & $\begin{array}{l}\text { The } 49 \text { Least Developed } \\
\text { Countries (LDCs) }\end{array}$ \\
\hline $\begin{array}{l}\text { Special } \\
\text { Climate } \\
\text { Change Fund } \\
\text { (SCCF) }\end{array}$ & $\begin{array}{l}\text { Facilitate programs relating to adaptation, } \\
\text { among other areas } \\
33\end{array}$ & $\begin{array}{l}\text { - About } \$ 150 \text { million for } \\
39 \text { projects } \\
\text { - Two projects reaching } \\
\text { completion and } 17 \text { starting } \\
\text { implementation } 34\end{array}$ & All developing countries \\
\hline $\begin{array}{l}\text { Global } \\
\text { Environment } \\
\text { Facility (GEF) } \\
\text { Strategic Pri- } \\
\text { ority on Adap- } \\
\text { tation (SPA) }\end{array}$ & $\begin{array}{l}\text { Support activities within the areas of } \\
\text { information and methodologies }+ \\
\text { vulnerability and adaptation, including } \\
\text { the establishment of adaptation pilot } \\
\text { projects } 35\end{array}$ & $\begin{array}{l}\text { - } \$ 50 \text { million to } 26 \text { projects } \\
\text { - The original funds were all } \\
\text { distributed by } 2010\end{array}$ & $\begin{array}{l}\text { All countries eligible for GEF } \\
\text { funding generally }{ }^{37}\end{array}$ \\
\hline $\begin{array}{l}\text { Adaptation } \\
\text { Fund }\end{array}$ & $\begin{array}{l}\text { Assist developing countries that are } \\
\text { particularly vulnerable to the adverse } \\
\text { effects of climate change }\end{array}$ & $\begin{array}{l}\text { About } \$ 166 \text { million for } \\
25 \text { projects }^{39}\end{array}$ & $\begin{array}{l}\text { Developing country parties } \\
\text { to the Kyoto Protocol }\end{array}$ \\
\hline
\end{tabular}

28 See Bonizella Biagini and Saliha Dobardzic, "Accessing Resources under the Least Developed Countries Fund", May 2011 , at 7, available on the Internet at $<$ http://www.thegef.org/ gef/sites/thegef.org/files/publication/23469_LDCF.pdf> (last accessed on 25 July 2013).

29 See Decision 1/CP.6, Implementation of the Buenos Aires Plan of Action, UN Doc. FCCC/CP/2000/5/Add.2, 4 April 2001; Decision 5/CP.6, The Bonn Agreements on the Implementation of the Buenos Aires Plan of Action, UN Doc. FCCC/CP/2001/5 25 September 2001.

30 See Decision 29/CP.7, Establishment of the Least Developed Countries Expert Group, UN Doc. FCCC/CP/2001/13/Add.4, 21 January 2002.

31 lbid.

32 See Global Environment Facility, Least Developed Countries Fund, available on the Internet at <http://www.thegef.org/gef/ LDCF> (last accessed on 25 July 2013).

33 See Decision 5/CP.6, supra, note 30 (The SCCF also funds programs relating to transfer of technologies; energy, transport, industry, agriculture, forestry, and waste management; and economic diversification of fossil fuel dependent countries.).

34 See Global Environment Facility, Special Climate Change Fund, available on the Internet at <http://www.thegef.org/gef/SCCF> (last accessed on 25 July 2013).

35 See Decision 5/CP.7, at para. 7, Implementation of Article 4, Paragraphs 8 and 9, of the Convention, UN Doc. FCCC/CP/ 2001/13/Add.1, 21 January 2002 (The pilot projects aim "to show how adaptation planning and assessment can be practically translated into projects that will provide real benefits.").
36 See Global Environment Facility, Evaluation of Strategic Priority for Adaptation, at 13, available on the Internet at <http://www.thegef.org/gef/sites/thegef.org/files/documents/ spa-fullreport-LR.pdf> (last accessed on 16 June 2013); Global Environment Facility, Strategic Priority for Adaptation, available on the Internet at <http://www.thegef.org/gef/SPA> (last accessed on 25 July 2013).

37 See Global Environment Facility, Strategic Priority for Adaptation, available on the Internet at <http://www.thegef.org/gef/SPA > (last accessed on 25 July 2013).

38 See Kyoto Protocol to the United Nations Framework Convention on Climate Change, 10 December 1997, in force 16 February 2005, 37 International Lega/ Materials (1998), Art. 12, para. 8 Countries that are vulnerable to the adverse effects of climate change include "low-lying and other small island countries; countries with low-lying coastal, arid, and semi-arid areas or areas liable to floods, drought, and desertification; and developing countries with fragile mountainous ecosystems." Adaptation Fund Board, Operational Policies and Guidelines for Parties to Access Resources from the Adaptation Fund, Annex 1, para. 10, available on the Internet at <http://adaptation-fund.org/sites/ default/files/OPG\%20Revised\%204.4.12\%20(with\%20annexes). pdf> (last accessed on 25 July 2013).

39 See UNFCCC, Adaptation Fund project data 2012, available on the Internet at <http://unfccc.int/cooperation_and_support/ financial_mechanism/adaptation_fund/items/6668.php> (last accessed on 25 July 2013).

40 See Decision 10/CP.7, at para 1, Funding under the Kyoto Protocol, UN Doc. FCCC/CP/2001/13/Add.1, 21 January 2002 (The Adaptation Fund is rooted in Article 12.8 of the Kyoto Protocol, which requires that some proceeds from certified project activities, here the Clean Development Mechanism (CDM), are used for adaptation programs.). 


\begin{tabular}{|c|c|c|c|}
\hline Fund & Purpose & Money Allocated & Countries Eligible \\
\hline $\begin{array}{l}\text { Green Climate } \\
\text { Fund }^{41}\end{array}$ & $\begin{array}{l}\text { Assist mitigation and adaptation measures } \\
\text { of developing countries }\end{array}$ & $\begin{array}{l}\text { - Goal of mobilizing } \\
\$ 100 \text { billion/year by } 2020^{42} \\
\text { - Germany, Denmark, and the } \\
\text { Republic of Korea have com- } \\
\text { mitted money (late } 2011)^{43} \\
\text { with no money disbursed yet }\end{array}$ & $\begin{array}{l}\text { COP17 in Durban decided that } \\
\text { interim arrangements within the } \\
\text { GEF for the Green Climate Fund } \\
\text { would finish by } 2013.44\end{array}$ \\
\hline $\begin{array}{l}\text { Fast-Start } \\
\text { Financing } 45\end{array}$ & $\begin{array}{l}\text { Assist mitigation and adaptation measures } \\
\text { of developing countries }\end{array}$ & $\begin{array}{l}\text { Goal of mobilizing } \$ 30 \text { billion } \\
\text { for } 2010-2012 \text { with a } \\
\text { balanced allocation between } \\
\text { mitigation and adaptation } 46\end{array}$ & $\begin{array}{l}\text { LDCs, small island developing } \\
\text { states, and African countries } \\
\text { receive first priority } 47\end{array}$ \\
\hline
\end{tabular}

The basic mandates of the Least Developed Countries Fund (LDCF), Special Climate Change Fund (SCCF), and Adaptation Fund emphasize adaptation that has tangible co-benefits. This requirement appears to manifest itself as an emphasis on adaptation projects that promote adaptation to climate variability (present climate stressors) and climate resilience in the short run while shortchanging state-of-the-art climate change forecasts and adequate preparation for the predicted impacts of longterm climate change. The Strategic Priority on Adaptation (SPA) similarly tends to fund projects that address climate variability instead of climate change, despite Global Environment Facility (GEF) guidance indicating that SPA adaptation projects should be "prepared using a rigorous scientific approach consistent with best practice as represented by recognized international authorities, peerreview processes and peer-reviewed publications." ${ }^{148}$

$\mathrm{COP}_{7}$ decided that adaptation activities funded by the LDCF and SCCF should follow a "country- driven approach that allows developing country Parties to pursue the specific activities most appropriate to their unique national circumstance." 49 This mandate often leads to an emphasis on "adaptation as development" and on "win-win, no-regret strategies" that are useful independent of what climate forecasts predict but may not provide adequate preparation for long-term climate change. In 2010, a team of technical and policy experts from the GEF prepared an evaluation of the SCCF that reviewed the relevancy of the SCCF to the goals of the UNFCCC and recipient countries, the effectiveness and efficiency of the SCCF at achieving its desired outcomes, and the results of the funding. The evaluation found:

The limited availability of local climatic data as well as the inadequate ability to analyze them to generate pertinent information stands out as a significant barrier when designing adaptation activities. While current available climatic data and modeling increasingly allows for predictions
41 Interim arrangements within the GEF are expected to finish by 2013. See Decision 11/CP.17, at para 19, Report of the Global Environment Facility to the Conference of the Parties, UN Doc. FCCC/CP/2011/9/Add.2, 15 March 2012.

42 See Decision 2/CP.15, Copenhagen Accord, UN Doc. FCCC/CP/ 2009/11/Add. 1, 30 March 2010. It seems the $\$ 100$ billion per year figure for the Green Climate Fund was based on a 2010 World Bank study that estimated the cost of adapting the developing world to a $2^{\circ} \mathrm{C}$ warmer world by 2050 to be in the range of $\$ 75$ billion to $\$ 100$ billion a year. World Bank, The Cost to Developing Countries of Adapting to Climate Change (2010), available on the Internet at $<\mathrm{http}: / /$ siteresources.worldbank.org/ EXTCC/Resources/EACC-june2010.pdf> (last accessed on 25 July 2013).

43 See Decision 11/CP.17, supra, note 42, at para. 26.

$44 \mathrm{Ibid}$. at para. 19.

45 Countries have channeled money through the UNFCCC funds as well as through direct government spending and private investment dedicated to specific projects.
46 According to the World Resources Institute, developed countries have delivered over $\$ 33$ billion in fast-start financing. However, it is unclear whether or not the money is being allocated in a way that meets the three fast-start financing goals: a "balanced" allocation between adaptation and mitigation, a prioritization of the most vulnerable developing countries, and a new and additional commitment compared to traditional development funding. See Taryn Fransen, "Fast-Start Finance: Where Do We Stand at the End of 2012?," World Resources Institute, 4 December 2012, available on the Internet at <http://insights.wri.org/openclimate-network/2012/12/fast-start-finance-where-do-we-standend-2012 > (last accessed on 25 July 2013).

47 United Nations Framework Convention on Climate Change, Conference of the Parties, Submissions on Information from Developed Country Parties on the Resources Provided to Fulfill the Commitment Referred to in Decision 1/CP.16, Paragraph 95 3-4, UN Doc. FCCC/CP/2011/INF.1, 15 August 2011.

48 Global Environment Facility, GEF Council, Piloting an Operational Approach to Adaptation, at 2, UN Doc. GEF/C.27/Inf.10, 14 October 2005.

49 Decision 5/CP.7, supra, note 36, at 91. 
at global and regional scales, the ability to more precisely project local climate change and variability as well as its associated impacts remains low. The downscaling of climate modeling data as also employed by several SCCF projects ... can somewhat improve the data situation, but cannot provide precise information at the project level. This limitation reduces the ability to design and implement targeted and location specific adaptation activities... Instruments employed by SCCF projects [to interpret existing knowledge] include meta-analyses of existing materials, available climate variability data and climate change projections when available supplemented by sector specific data related to the project as well as use of existing downscaled climate modeling information. 50

Although the SCCF has funded some projects that respond to forecasts for long-term climate change, ${ }^{51}$ the Fund's general emphasis on local data and downscaling of climate modeling can often ignore the information available through climate change forecasts, which are most accurate and predictive at the regional and global scales and over a long timeframe.

A GEF evaluation of the SPA produced similar conclusions. "Adaptation to climate change starts with an understanding of coping strategies for dealing with the extremes evidenced in current climate variability. Often times, it will be operationally impossible to attribute a given extreme to climate variability or climate change. As a result, GEF will sup port adaptation measures under this pilot aimed at coping with current variability as well as climate change." 52 In 2011 , the GEF completed an evaluation of the SPA indicating that the scientific and technical input and review were fairly uncoordi-

50 Global Environment Facility, Evaluation of the Special Climate Change Fund, at 46, October 2011, available on the Internet at <http://www.thegef.org/gef/sites/thegef.org/files/documents/ Evaluation\%20for\%20SCCF.pdf> (last accessed on 25 July 2013).

51 See, e.g., Global Environment Facility, Detail of GEF Project \#2902, Adaptation to the Impact of Rapid Glacier Retreat in the Tropical Andes, available on the Internet at $<$ http://www.thegef.org/gef/project_detail?projID=2902> (last accessed on 25 July 2013).

52 Piloting an Operational Approach, supra, note 49, at 6.

53 See Evaluation of SPA, supra, note 37, at 9.

$54 \mathrm{lbid}$. at 36 ("The analysis of SPA projects ... reveals that, while all the projects do provide a climate change rationale, the degree nated ${ }^{53}$ and that the climate change rationale for projects was not always fully supported with scientific evidence. ${ }^{54}$ of utmost importance is this conclusion from the evaluation: many projects struggled to provide a precise scientific rationale because of a lack of localized and applicable climate data and models. ${ }^{55}$ In part because of these difficulties, "the types of adaptation measures selected were similar to measures that would be applied regardless of climate change." ${ }^{n 6}$

The COP decisions and guidance documents from the Global Environment Facility (GEF) and Least Developed Countries Expert Group (LEG) all provide information as to how the UNFCCC funds should be run. Nonetheless, adaptation projects submitted to all funds are often directly implementing or are informed by proposals outlined in countries' National Adaptation Programmes of Action (NAPA), ${ }^{57}$ so any guidance for NAPA development provided by the COPs, the LDCF, the GEF, the LEG, or any other entity effectively becomes the guidance for the funds themselves. A NAPA provides information on a country's general environmental, social, and geographic setting as well as on observed and projected climate variability and climate change within the country and beyond. With this information, a NAPA identifies key adaptation needs for the country and establishes priority adaptation activities. ${ }^{58}$ At its core, a NAPA serves as a "simplified and direct channel[] of communication for information relating to the urgent and immediate adaptation needs of the LDCs." ${ }^{29}$ This mandate, similar to those for the LDCF, SCCF, and Adaptation Fund, will likely produce NAPA project proposals aimed at adaptation to climate variability because it emphasizes adaptation to immediate vulnerabilities, not to the long-term impacts of climate change.

\footnotetext{
to which these arguments are developed according to scientific and participatory principles varies greatly. For example, ...

11 projects provided no evidence of participatory processes

(for climate assessments or otherwise), and 7 projects had no reference to climate change scenarios.").

$55 \mathrm{lbid}$. at 8 .

$56 \mathrm{lbid}$. at 37.

57 See Decision 5/CP.6, supra, note 30, at paras. 1(c) and (2); Operational Policies, supra, note 39, at Annex 1, paras. 6-7.

58 Decision 28/CP.7, Guidelines for the Preparation of Nationa Adaptation Programmes of Action, UN Doc. FCCC/CP/2001/13/Add.4, 21 January 2002.
}

59 Decision 5/CP.6, supra, note 30, at para. 15. 
Indeed, the first step in the NAPA preparation process is the establishment of a national NAPA team that reviews available information on climate change and conducts "a participatory assessment of vulnerability to current climate variability and extreme weather events, and to assess where climate change is causing increases in associated risks. ${ }^{n 0}$ The LEG advises the NAPA team to rely on scenarios derived from general circulation models, ${ }^{61}$ disaster preparedness plans, meteorological data, Intergovernmental Panel on Climate Change (IPCC) assessment reports, climate variability data, climate change scenarios, and the like. ${ }^{62}$ However, the UNFCCC Subsidiary Body for Implementation (SBI) has cautioned that IPCC reports may provide conclusions that are too broad to apply to $\mathrm{LDCs}^{63}$ but that "recent trends in climate parameters, such as temperature and rainfall distribution, are probably useful indicators of potential trends over the short to medium term. ${ }^{n 4}$ Many sources emphasize the valuable information available at the local level regarding major climatic hazards and traditional adaptation strategies; ${ }^{65}$ some even prioritize local knowledge over scenario-based modeling in making vulnerability assessments and identifying priority activities. ${ }^{66}$ For example, the GEF and LEG indicate that "it should not be necessary to have to demonstrate exact mechanisms by which droughts impact upon water and agricultural production, and so, food security." ${ }^{\prime 67}$

While this approach is certainly appropriate for adaptation to climate variability, it is insufficient for adaptation to long-term climate change. First, future

60 Decision 28/CP.7, supra, note 59. See also Least Developed Countries Expert Group, National Adaptation Programmes of Action: Overview of Preparation, Design of Implementation Strategies and Submission of Revised Project Lists and Profiles, available on the Internet at <http://unfccc.int/resource/docs/ publications/ldc_tp2009.pdf > (last accessed on 25 July 2013).

61 See U.N. Framework Convention on Climate Change, Least Developed Countries Expert Group, Synthesis of Available Information for the Preparation of National Adaptation Programmes of Action, at 5, UN Doc. FCCC/TP/2005/2, 18 November 2005.

62 See NAPA Overview, supra, note 61, at 10.

63 See Synthesis, supra, note 62, at 4.

$64 \mathrm{lbid}$. at 6.

65 See NAPA Overview, supra, note 61, at 11.

66 See UNFCCC, Chronological Evolution of LDC Work Programme and Concept of NAPAs, available on the Internet at <http://unfccc.int/cooperation_support/least_developed_countries_portal//dc_work_programme_and_napa/items/4722.php> (last accessed on 25 July 2013) ("The NAPA takes into account existing coping strategies at the grassroots level, and builds upon climate change should not be extrapolated from recent trends, in part because the latter have been influenced by aerosol pollution and such influence is likely to be much different in the future, as some countries reduce aerosol emissions and manufacturing moves to new regions. Second, as discussed in Part II, climate change might bring forth vulnerabilities that are not well sampled in the historical experience. One example is sea level rise, and another is the unprecedented seasonal heat.

Although the funds struggle to differentiate between adaptation to climate variability and climate change (or struggle to enforce this differentiation), the SPA and, as of May $2011,{ }^{68}$ the LDCF and SCCF are complimented by the Scientific and Technical Advisory Panel (STAP), a six-member panel established by the United Nations Environment Programme (UNEP) that provides independent, strategic scientific advice. ${ }^{69}$ The panel screens project proposals in the early stages of the GEF review process to determine as soon as possible "whether a project proposal could benefit from high-level scientific advice in its further preparation and whether the project proponents have the necessary access to and understanding of recent advances in the relevant aspects of science and technology." 70 According to an interview with representatives from the GEF, the STAP will notify the GEF if the scientific rationale for a project is inadequate. ${ }^{71}$ In almost all instances, the GEF will work with the applicant to revise the application such that the project can ultimately be funded. The STAP is a helpful resource for project applicants and review-

that to identify priority activities, rather than focusing on scenario-based modeling to assess future vulnerability and longterm policy at state level.").

67 Least Developed Countries Expert Group, Step-by-Step Guide for Implementing National Adaptation Programmes of Action, at 4, available on the Internet at <http://unfccc.int/resource/docs/ publications/ldc_napa2009.pdf (last accessed on 25 July 2013).

68 See Global Environment Facility, LDCF/SCCF Council, The Science of Adaptation: The Role of STAP in the LDCF and SCCF, UN Doc. GEF/LDCF.SCCF.10/5/Rev.2, 24 May 2011.

69 See Terms of Reference of the Scientific and Technical Advisory Panel, March 2012, available on the Internet at <http://stapgef.org/statutes> (last accessed on 25 July 2013).

70 UNEP, Screening of PIFs in the Project Cycle Document available on the Internet at <http://www.unep.org/stap/ ScreeningofPIFsintheProjectCycleDocument/tabid/2913/ language/en-US/Default.aspx> (last accessed on 25 July 2013).

71 Telephone interview with Claudia Ortiz, Junior Professional Associate, Global Environment Facility, and Junu Shrestha, Operations Analyst, Global Environment Facility, 27 February 2012. 
ers; however, the evidence presented above indicates that the Panel could play a much stronger role than it historically has in emphasizing adaptation to climate change and the application of state-of-theart climate science.

The fast-start financing program and Green Climate Fund provide areas of promise for climate change adaptation funding; however, as of this writing, the UNFCCC has not published any decisions that establish specific requirements for the disbursement of money from these funds. The Green Climate Fund website indicates that the Fund will follow "a country-driven approach and promote and strengthen engagement at the country level through effective involvement of relevant institutions and stakeholders." ${ }^{72}$ Similar to the LDCF and SCCF requirement that countries pursue projects appropriate to their unique national circumstance, the Green Climate Fund has a national focus that may similarly emphasize "adaptation as development" and "win-win, no-regret strategies" that are beneficial but also unnecessarily limiting in a way that shortchanges the usefulness of climate forecasts. The basic structure of the Green Climate Fund is still being developed however, so much remains to be seen about how the Fund operates.

In summary, the guidance documents for and evaluation reports of the four primary adaptation funds indicate that there is little formal guidance on the role climate change forecasts should play in decision-making. They also show that countries, United Nations agencies, and the funding agencies themselves struggle to incorporate climate forecasts into project planning and funding review. Because of the lack of formal guidance on what role forecasts should play in project planning, the difficulty of integrating climate forecasts, and the mandates of the UNFCCC and COP decisions, project applicants and the funding agencies ultimately rely heavily on historical vulnerability to climate variability to guide decision making on climate change adaptation and emphasize development, resilience, and no-regret projects. The following sections indicate a similar pattern in other funding sources.

72 Green Climate Fund, Mandate and Governance, available on the Internet at <http://gcfund.net/about-the-fund/mandateand-governance.html> (last accessed on 25 July 2013).

73 See Global Environment Facility, GEF Agencies, available on the Internet at <http://www.thegef.org/gef/gef_agencies>

\section{Non-UNFCCC Funding Sources}

The primary non-UNFCCC funding sources include UN organizations, multilateral development banks (MDBs), and bilateral and multilateral arrangements among countries. UN organizations and MDBs can fund climate change adaptation through their own initiatives or by managing UNFCCCfunded projects, which must be implemented by a UN organization or MDB in partnership with the country project proponent. The Global Environmental Facility and the Adaptation Fund maintain lists of the organizations and banks approved to manage UNFCCC-funded projects. ${ }^{73}$

The following discussion reviews only organizations and programs that emphasize a contribution to climate change adaptation and does not consider the many entities with a sole mandate to engage in disaster risk management, which is only a small part of climate change adaptation and does not aid the evaluation of the role of climate change forecasts in adaptation planning. As revealed below, the non-UNFCCC sources of funding - MDBs, agreements among countries, and mixed programs - generally exhibit a similar emphasis on adaptation to climate variability and on climate resilience as do the UNFCCC funds. Some bilateral and multilateral agreements among countries reveal a greater understanding of the difference between adaptation to climate change and adaptation to climate variability and use accurate and comprehensive forecasts relative to the MDBs and mixed programs. Nonetheless, there does not appear to be any program or organization that is fully dedicated to climate change adaptation informed by accurate long-term climate models and forecasts.

\section{a. Multilateral Development Banks}

The review in this section draws on two MDBs with readily accessible climate change strategies and information: the World Bank and the African Development Bank. (last accessed on 25 July 2013) (providing additional information about the comparative advantage of selecting a particular organization to support an adaptation project); Adaptation Fund Implementing Agencies, <http://adaptation-fund.org/node/9> (last accessed on 25 July 2013). 
In October 2009 the World Bank published a climate change resiliency strategy for Sub-Saharan Africa, which is the primary source analyzed here. The strategy is focused on adaptation to climate variability as a way of preparing countries for eventual climate change, ${ }^{74}$ an adaptation strategy similar to that revealed in some guidance materials for the UNFCCC funds. The World Bank's work prioritizes "actions that will support and/or accelerate ongoing development efforts while making them more resilient to climatic risks, ${ }^{n 5}$ even though ongoing development efforts may be - and likely are, given evidence from the UNFCCC funds based on past climate data rather than climate change forecasts or may not be geared to climate change adaptation at all. The forecasting in the World Bank strategy is generally accurate, explaining that climate change is subject to many uncertainties, that temperature in Africa is expected to increase significantly, and that rainfall changes will be inconsistent. ${ }^{76}$ However, with the stated interest in tackling adaptation to climate variability first, it is no surprise that, "in consultation with client countries and development partners, the main focus over the next three fiscal years (2010 to 2012) is on ... short-term to medium-term results, which will be monitored through sector operations and an annual report on the implementation of the regional climate strategy."77 Many of the priorities in Sub-Saharan Africa will contribute to climate change adaptation, such as testing new crop varieties and scalingup land management programs; ${ }^{78}$ however, without a long-term vision and the support of accurate climate change forecasts, these programs risk falling short of adaptation to long-term climate change.

The African Development Bank (AfDB) produced a climate risk management strategy in April 2009, which is the primary source analyzed here. The strategy generally speaks of adaptation to climate change and climate variability together and, similar to the World Bank strategy, of promoting climate resilience in current and future projects. ${ }^{79}$ The tendency to conflate climate variability with climate change is still evident, however: "The impact of climate change on development is multifaceted. ... Second, climate variability has a major impact on the performance of developing economies especially, because of their high dependence on natural resources, including rain-fed agriculture. ... Fifth, climate variability and extreme events compromise the sustainability and performance of economic and social infrastructure assets and reduce the economic and financial rates of return. ${ }^{n 0}$ While the statements in the excerpt regarding the impact of climate variability are true, they do not reflect an understanding that the impacts of climate variability are different from those of long-term climate change and that adaptation to variability may not be adequate for successful adaptation to climate change.

\section{b. Agreements among Countries}

The review in this section draws on two initiatives that provide funding for adaptation through agreements among countries and that had readily accessible climate change strategies and information: the European Union's Global Climate Change Alliance (GCCA) and the United States' Feed the Future (FTF) Initiative.

GCCA provides technical and financial support to adaptation and mitigation projects in developing countries and has committed over $€ 200$ million, including fast-start financing. ${ }^{81}$ The GCCA pub-

\footnotetext{
74 See World Bank, "Making Development Climate Resilient: A World Bank Strategy for Sub-Saharan Africa", at xix, 30 October 2009, available on the Internet at <http://siteresources. worldbank.org/INTAFRICAResources/ClimateChange-Strategy Report2010-Full_vNolmages.pdf> (last accessed on 25 July 2013); Press Release, World Bank, World Bank Climate Change Strategy for Africa Calls for Adaptation, Mitigation and Additional Financing, 30 November 2010, available on the Internet at <http://web.worldbank.org/WBSITE/EXTERNAL/COUNTRIES/ AFRICAEXT/0,,contentMDK:22777785 menuPK:2246551 pagePK:2865106 piPK:2865128 theSitePK:258644,00.html> (last accessed on 25 July 2013).

75 World Bank Strategy, supra, note 75 , at xvi.

76 lbid. at xviii, xxii-xxiii.
} 
lished a report in 2011 entitled "Using Innovative and Effective Approaches to Deliver Climate Change Support to Developing Countries," which is the primary source analyzed here. Unlike World Bank and AfDB climate change strategies, the GCCA report does not use the phrase climate variability at all and appears to focus on climate change adaptation. For example, the GCCA funded a project in Ethiopia to strengthen the institutional capacities of the government, develop knowledge on climate change, and field test climate change interventions. The climate change analysis in the 2011 report regarding the Ethiopia project accurately depicts the anticipated impacts and suggests an appropriate course of action: "Ethiopia faces uncertainty over rainfall and climate models suggest that the country will see further warming of between 0.7 and 2.3 degrees Celsius by 2020. Climate change has already led to an increasing number of hot days and the effects on crop and livestock production threaten food and water shortages, further hindering economic growth. For these reasons, the GCCA is supporting a programme which ... include[s] the rehabilitation of degraded watersheds, enhancing soil and nutrient management, improving crop choice and planting management, water use efficiency, and farmers' access to market opportunities and storage facilities. $^{\text {" }}{ }^{2}$

FTF supports country-driven approaches to solving global hunger and poverty and to provide longterm solutions to food insecurity. ${ }^{83}$ The program has provided about $\$ 111$ million to Ethiopia since 2008 and $\$ 100$ million to Senegal since 2008 , as well as millions of dollars to countries outside of the Sahel. ${ }^{84}$ FTF supports soil and water management, livestock and fisheries protection, and plant breeding and technology. The "crop research projects are making important steps toward resilience by identifying ways to breed seeds that incorporate tolerance to disease, heat, and drought to increase production while maintaining or improving the nutritional quality of food. ${ }^{85}$ It is unclear how much this strategy accounts for the complex interplay between temperature and rainfall described in Part II of this article; however, the emphasis on crop research generally is important for successful adaptation to climate change, especially when it accounts for temperature increases.

In summary, the agreements among countries to provide financing for climate change adaptation profiled above provide mixed conclusions about the role of climate change forecasts in adaptation planning and funding. Compared to the MDBs, these agreements among countries generally exhibit a greater understanding of the difference between adaptation to climate change and adaptation to climate variability. There has been no detailed investigation into this difference in focus between country donors and bank donors; however, a potential cause might be the countries' flexibility and freedom to develop long-term, in-depth relationships with donee countries and programs, possibly allowing the donors to understand better than banks the projected climate change impacts in certain regions and the paths to long-term adaptation. Donor banks, compared to donor countries, may be more focused on short-term, quantitative results (possibly because of the banks' large portfolio of projects or because of their global bureaucracy), leading them to emphasize adaptation to climate variability.

\section{c. Mixed Programs}

The review in this section draws on a variety of programs established and administered by a mix of individual countries, MDBs, and UN organizations that provide funding for adaptation and that had readily accessible climate change strategies and information. The programs generally focus on adaptation to climate variability and on climate resilience, similar to the MDBs' individual adaptation programs discussed above.

The Climate Investment Funds Strategic Climate Fund's Pilot Program for Climate Resilience (PPCR) was founded in 2008 by a mix of MDBs and has received a commitment of $\$ 1$ billion to date. The

$82 \mathrm{lbid}$. at 20-21.

83 See Feed the Future, "About", available on the Internet at $<$ http://www.feedthefuture.gov/about> (last accessed on 25 July 2013).

84 See Feed the Future, "Ethiopia", available on the Internet at <http://www.feedthefuture.gov/country/ethiopia> (last accessed

on 25 July 2013); Feed the Future, Senegal, available on the Internet at <http://www.feedthefuture.gov/country/senegal> (last accessed on 25 July 2013).

85 Feed the Future, "Climate Change and Food Security Fact Sheet", available on the Internet at <http://www.feedthefuture.gov/ approach/Environment-Sensitive-Development\#focus-areas> (last accessed on 25 July 2013). 
projects funded by the PPCR are built on countries' NAPAs and are guided by UNFCCC principles, ${ }^{86}$ and the projects indeed fall prey to an emphasis on adaptation to climate variability and on climate resilience similar to projects supported by the UNFCCC funds. The PPCR's selection process for pilot projects in the Sahel completely focuses on risks associated with water and ultimately finds that few conclusions can be drawn about the future of rainfall in the Sahel. ${ }^{87}$ As discussed in Part I, the absence of temperature increases from a discussion about climate change in the Sahel indicates that adaptation will be incomplete and possibly misguided.

ClimAfrica runs from October 2010 through September 2014 on $€_{4} .6$ million and focuses on responding to an urgent need for "appropriate and up-to-date tools to better understand and predict climate change in Africa, assess its impact on African ecosystems and population, and develop the correct adaptation strategies. ${ }^{n 8}$ The program aims to collect and analyze past climate data and use this information to model seasonal to decadal climate scenarios. The program then will quantify the sensitivity of agriculture and water resources to this variability and will establish a monitoring and forecasting warning system for the next 10 years. With this information as well as economic assessments of adaptation versus no action, the program will develop case studies to highlight specific adaptation strategies. ${ }^{89}$ While the forecasting warning system is clearly addressing the need to respond to climate variability, this program has the potential to better understand the vulnerability of Sahelian agriculture to the growing risks of heat waves and extreme rainfall events, in similar fashion as was shown in Figure 2.

The Advancing Capacity for Climate Change Adaptation (ACCCA) program looks at climate variability over the short term. The program finished in 2009 and was created by a variety of organizations, from the UN Institute of Training and Research to the University of Cape Town's Climate Systems Analysis Group. ${ }^{90}$ The program recognized the importance of climate change models and longterm projections but found that such information was often at geographic and time scales that are too broad for use by developing countries. ${ }^{91}$ The scientific support for pilot actions appears to be based on observed climate changes in recent decades using historical meteorological data, but a synthesis of the program also discusses modeling that was done. "In general, pilot action teams recognize the value of models to simulate scenarios and generate relevant information for more robust decision-making and implementation of win-win adaptive practices. However, they are also aware of the lack of in-country capacity to use models, and particularly the lack of data availability (spatial coverage and time series) to generate reliable model outputs." ${ }^{12}$ ACCCA projects generally aimed to understand climate variability over the next two to ten years and at the community and regional levels, and ACCCA reserved for future work the task of longterm climate change modeling and adaptation. ${ }^{93}$

89 See ClimAfrica, "Themes", available on the Internet at <http://www.climafrica.net/themes_past_en.jsp> (last accessed on 25 July 2013).

90 See START, "Advancing Capacity for Climate Change Adaptation", available on the Internet at <http://start.org/ programs/accca> (last accessed on 25 July 2013).

91 See Brochure, "Communicating Climate Risks: Insights Gained through the ACCCA Project", available on the Internet at <http://start.org/programs/accca> (last accessed on 25 July 2013); Fernanda Zermoglio and Tahia Devisscher, "Synthesis Report: Lessons Learned on Climate Change Science and Risk Communication in the ACCCA Project", at 28, 30 June 2009, available on the Internet at <http://start.org/download/acccasynthesis.pdf $>$ (last accessed on 25 July 2013).

92 Zermoglio, supra, note 92 , at 12-17.

$93 \mathrm{lbid}$. at 28. 


\section{Adaptation in Practice}

The frameworks for climate change adaptation funding sources discussed above provide valuable insights into the role of climate change forecasts or lack thereof - in adaptation planning and funding. There is also evidence from adaptation in practice that similarly reveals an emphasis on adaptation to climate variability over adaptation to climate change. The sections below relay first-hand observations of the negotiations and events at COP16 in Cancun in 2010 and COP17 in Durban in 2011 as well as review the use of climate change forecasts in the development of an SCCF-funded adaptation project in Ethiopia.

\section{COP Negotiations and Side Events}

Fellows from the Columbia Center for Climate Change Law sat in on COP16 and COP 17 official negotiations and meetings as well as side events where parties, UN agencies, and observer organizations presented information on new research, successful collaborations, recent policy developments, and the like. At both COPs, the fellows found that delegates in plenary sessions, contact group meetings, and information consultations generally focused on developing frameworks for new or revised institutions and programs, and while the delegates appeared to be aware of general climate change trends and impacts, they did not discuss data or forecasts. For example, there was a Subsidiary Body for Scientific and Technological Advice (SBSTA) meeting in Durban dedicated to creating an annual forum to review the effectiveness of capacity building in adaptation planning. Decision-making at this level of generality did not seem to warrant a scientific discussion, although it is possible that research and data reviewed outside the negotiations did inform the nature of the decisions.

The side events proved to be the more appropriate forums for an examination of the type of climate change research and forecasting being pro duced around the world and of how such science influences climate change adaptation project planning and funding. The presentations at the side events generally showcased organizations and multilateral programs that aim to provide climate monitoring and prediction tools, improved climate change forecasting, mitigation and adaptation strategies, and capacity-building assistance. ${ }^{94}$ Despite the wealth of resources available through such organizations and programs, a resounding message of the side events was that existing climate models, generally at the global or continental scale, were of minimal use to local stakeholders, who expressed an immediate need for regional and local climate forecasts ("downscaled" forecasts) that would allow them to adapt to climate change in the near term. For example, a presentation by the Malian Meteorological Service discussed the impacts of rainfall variability on agriculture, and the Zambezi Watercourse Commission expressed urgency in adapting to climate variability because of its impact on people's daily lives. In what may be a response to such exhortations, government programs such as the United Kingdom Met Office Hadley Centre's Climate Science Research Partnership and the United States National Oceanic and Atmospheric Administration's Climate Prediction Center have begun preparing regional climate forecasts and researching how to downscale global climate information.

The focus on adapting to climate variability and downscaling climate information is of no surprise given what appears to be an institutionalized emphasis on adaptation to climate variability in the UNFCCC funds and non-UNFCCC funding sources discussed above. Many programs and organizations at the side events reported success in increasing technology transfer and information sharing among countries, which will be helpful as developing countries adapt to climate change. However, the numerous examples of enhanced drought monitoring methods and early warning systems as well as water management strategies and irrigation programs underscore how development and climate resilience are considered the dominant mechanisms for climate adaptation.
94 Examples include: ClimDev-Africa, which aims to improve the provision and use of climate information in African adaptation planning; ICPAC-IGAD, which aims to foster sub-regional and national capacity for climate information, prediction products and services, and early warning applications for sustainable development; and the Climate Science Research Partnership which aims to improve the understanding and practical prediction of African climate to help alleviate poverty. 


\section{Ethiopia Adaptation Project Review}

The case study discussed below is an adaptation project from Ethiopia ${ }^{95}$ entitled "Coping with Drought and Climate Change." It started in March 2009 and was funded by the SCCF. ${ }^{96}$ This project is well suited to study because the project site is located within the African Sahel (a region to which climate science has paid much attention), the project has completed the funding cycle, and it is in the implementation stage. As discussed below, the emphasis on drought in the project proposal and implementation of the project ignores expected rainfall trends and fails to incorporate temperature projections, thereby limiting adaptation to climate variability alone.

The Ethiopian government initiated this project because of its concern that current weather patterns and future climate change will negatively impact Ethiopia's unstable agricultural and food supply system. Drought is already severe, with major events occurring every 3-5 years in some parts and every 6-8 years throughout Ethiopia, according to the project proposal. ${ }^{97}$ Agriculture is very important to Ethiopia's national economy and is very sensitive to water; the project proposal claims that a 10 $\%$ drop in rainfall below the long-term national average results in an average drop of $4.2 \%$ in cereal yields. ${ }^{98}$ In addition to concerns about agricultural impacts, the project proposal cites concerns that rising temperatures and falling rainfall trends will cause wildlife migration, reduced forest area, and the spread of malaria. ${ }^{99}$ According to the Conservation Strategy of Ethiopia cited in the project proposal, the frequency and intensity of drought are likely to increase in the future, as is the variability of the temporal and spatial distribution of rainfall.

Contrary to these assumptions, the Ethiopian NAPA recognizes that future increase in drought is

95 The project is also being implemented in Kenya, Zimbabwe and Mozambique through the SCCF funding. See Goshu Worku, "Achievements of Coping with Drought and Climate Change Project", at 3, February 2012, available on the Internet at <http://www.undp-alm.org/sites/default/files/downloads/ ethiopia_-_cwdcc_-_short_story_report_final.pdf $>$ (last accessed on 25 July 2013).

96 Ibid.; "Coping with Drought and Climate Change in Ethiopia: UNDP-ALM Project Profile/Case Study", March 2012, available on the Internet at <http://www.undp.org/content/dam/ethiopia/ docs/Final\%20Case\%20study.pdf> (last accessed on 25 July 2013).

97 See Global Environment Facility, "Medium-Sized Project Proposal, Coping with Drought and Climate Change" not the most likely scenario: while there is severe disagreement across models and large uncertainty in the rainfall projections for the Sahel (including Northern Ethiopia), the preponderance is for a very modest wetting. In this scenario, even increased variability would not cause increased drought. On the other hand, even with a moderate wetting, drought would continue to affect Ethiopia (especially as far north as the project site). An increase in the temporal and spatial variability of rainfall at the scale of weather events is likely, as it is considered a robust response to increases of atmospheric moisture in a warmer climate. Therefore, while a response to drought will likely be effective in reducing vulnerability to climate variability throughout the current century, such a response is not targeted to long-term climate change and might not be sufficient to prepare people in Northern Ethiopia for predicted impacts.

Consistent with the priority of resilience to current climate stressors, the Ethiopian government and the United Nations Development Programme (UNDP) proposed a project to develop and pilot coping mechanisms for reducing the vulnerability of farmers to drought. The targeted area for the project is Kalu Woreda in the South Wollo Zone. ${ }^{100}$

A variety of factors influenced the selection of Kalu Woreda as the project site. One was a vulnerability trend analysis by the Ethiopian Disaster Prevention and Preparedness Agency and Early Warning Working Group using the Chronic Vulnerability Index (CVI). "The CVI is an index used to identify levels of vulnerability for each food-insecure woreda in Ethiopia by analyzing and indexing various factors such as staple crop production per capita, livestock asset per capita, pasture quality and quantity, road accessibility, average prices of maize and sorghum, previous years' assessed needs, drought risk, prevalence of cash crop, and probabil-

7, 24 March 2006, available on the Internet at <http://www.thegef.org/gef/project_detail?projlD=3154>

98 Ibid.

99 Ibid. at 8.

100 Under the national government, Ethiopia has four tiers of local governance: regions (or states), zones (cluster of districts), woredas (or districts), and kebeles (wards or neighborhoods). See African Development Bank, "Federal Democratic Republic of Ethiopia: Country Governance Profile", at 17, March 2009, available on the Internet at <http://www.afdb.org/fileadmin/ uploads/afdb/Documents/Project-and-Operations/Ethiopia\%20$\% 20$ Country $\% 20$ Governance $\% 20$ Profile\%20EN.pdf $>$ (last accessed on 25 July 2013). 
ity of rainfall shocks." ${ }^{101}$ This analysis showed that Kalu Woreda experienced increased vulnerability over the study period due to decreased and variable rainfall as well as recurring droughts. ${ }^{102}$ Another factor influencing selection of Kalu Woreda was a 2003 study by the Amhara National Regional State Food Security Office, which concluded that "erratic and reduced rainfall, coupled with degraded rainfed agriculture," decrease agricultural yields in Kalu Woreda. ${ }^{103}$ The CVI, 2003 Food Security Office study, and stakeholder input ${ }^{104}$ all indicated that Kalu Woreda is chronically drought-prone and foodinsecure and very vulnerable to climate change.

The goals of the project are to, among others, enhance the resilience of vulnerable farmers within the pilot sites to cope with drought and climate change by (1) adopting and maintaining alternative livelihood strategies and sustainable land management practices such as organic farming, planting early maturing and high yielding cereal seeds, rice farming, and watershed management and (2) enhancing the woreda ${ }^{105}$ temperature and rainfall early warning system by developing partnerships among government stakeholders, installing household rain gauges and thermometers, analyzing local and satellite data, and sending simple and systematic messages to farmers. ${ }^{106}$ As a result of the project thus far, the UNDP reports that Goal 1 is being achieved in the following ways as a result of the project: operation of bee colonies as an alternative livelihood strategy as well as use of improved seeds and planting techniques, re-vegetation of watersheds to manage floods, improved irrigation, rotational foraging of sheep and goats, and rice planting as sustainable land management practices. As a result of the project, Goal 2 is being achieved by the reporting of rainfall and temperature data by house-

101 Project Proposal, supra, note 98, at 13.

$102 \mathrm{lbid}$. at 17.

$103 \mathrm{lbid}$. at 13.

$104 \mathrm{lbid}$. at 20-21.

105 See supra, note 101.

106 See Project Profile, supra, note 97, at 4-5.

107 lbid.

108 See Federal Democratic Republic of Ethiopia, "National Meteorological Services Agency: Initial National Communication of Ethiopia to the UNFCCC", at 75, June 2001, available on the Internet at <http://unfccc.int/resource/docs/natc/ethnc1.pdf> (last accessed on 25 July 2013) ("Predictions for rainfall did not manifest a systematic increase or decrease." For the long rain holds to an agriculture office, which produces a risk assessment from the household data and remote sensing data and disseminates it to the community. $^{107}$

The project proposal and implementation of the project are very clearly focused on drought conditions in Ethiopia and their impact on agriculture and food security. It is a good example of a no-regret project that deals with climate variability and extremes that are likely to be of concern in a wide variety of climate scenarios and supports resilience strategies that are universally beneficial. However, while the proposal includes scientific support for its assertion that drought has historically been a concern, it does not respond to a threat of worsening drought conditions under future climate change. This is because, as explained by the IPCC Assessment Reports, Ethiopia Initial Communication, ${ }^{108}$ and Ethiopia NAPA, ${ }^{109}$ worsening droughts are not the most likely outcome in the project site area. Projections are still very much uncertain, and while some models do suggest a possible decline in mean rainfall, most do not. The multi-model average projection is for increased rain; this was true when the adaptation project was developed and still is the case in the most recent climate simulations that will be the base of the IPCC fifth assessment report. ${ }^{110}$ A mean increase in seasonal rainfall would likely reduce future occurrences of drought, even in the presence of enhanced interannual variability. In addition, while rainfall will continue to be variable, temperature will increase dramatically. There is uncertainty in how much temperature will increase, linked in part to the uncertainty in rainfall changes, but all evidence point towards unprecedented heat and rainfall intensity. This project proposal does not address these impacts at all or the impacts

season (June-Sept), models generally indicated an increase of rainfall from $10-20 \%$ up to $50 \%$ for the project site. One model projected a decrease. For the short rain season (Feb-May), rainfall is expected to decrease. For the dry season (Oct-Jan), rainfall is expected to increase.)

109 See Federal Democratic Republic of Ethiopia, "National Meteorological Services Agency: Climate Change National Adaptation Programme of Action of Ethiopia", at 23, June 2007, available on the Internet at http://unfccc.int/resource/docs/ napa/eth01.pdf> (last accessed on 25 July 2013) ("A small increase in annual precipitation is expected over the country.").

110 See Biasutti, supra, note 17; R. Roehrig et al., "The Present and Future of the West African Monsoon: a Process-oriented Assessment of CMIP5 Simulations Along the AMMA Transect", Journal of Climate. doi:10.1175/JCLI-D-12-00505.1. 
resulting from the interplay between temperature and rainfall changes. As discussed in Part II, high temperatures can influence agricultural productivity in a variety of ways, from shortening crop duration to sterilizing reproductive organs. Heavy rainfall can increase soil erosion and wash away nutrients. Thus, while the emphasis on drought is not surprising in light of past and current vulnerabilities, such a narrow focus will likely be insufficient for the goal of adapting to the climate of the middle and end of the century.

\section{Recommendations}

Adaptation projects in the African Sahel appear to fulfill the mandates and guidelines articulated by the various funding sources described above; however, they are not going far enough to help countries get ahead of the curve and prepare for the emerging new climate. For a variety of reasons, funding entities and project planners are interested in promoting climate resilience and adaptation to climate variability as well as adaptation to climate change. Many project planners in developing countries express a need to prioritize adaptation to climate variability, given the urgent health, environmental, and even security threats facing these nations and given a general low capacity to evaluate complex climate data. The analysis above indicates that adaptation currently happens, in general, with an emphasis on climate variability that overwhelms significant attention to climate forecasts and the projected impacts of long-term climate change. This does not have to be the case, however. There are instances where adaptation to climate variability can go a long way in preparing people in developing countries for the projected impacts of climate change.

We recommend that the UNFCCC write funding guidelines that prioritize two types of projects: (1) projects that address risks that are increasing from historical levels (such as rainfall intensity and heat, versus drought) and (2) collaborative projects that emphasize technology transfer across geographic regions (such as new crop varieties). These two project types are preferable to many current projects financed by the UNFCCC funds because the two project types address climate variability, which is a pressing concern for many countries in the near term, in a way that also prepares countries for the predicted impacts of long-term climate change.
Specific examples of the first project type (projects that address risks that are increasing from historical levels) include:

- Flood control and early warning

Intense rainfall events have periodically led to widespread damage and loss of life throughout the Sahel. For example, in August 2010 floods in Niger inundated agricultural areas and worsened food security for many people. One approach to reducing flood damage is to improve early warning of flood events, and many NAPAs, including Niger's, contain projects with this goal. For example, the second highest priority in the Ethiopia NAPA was "strengthening/enhancing drought and flood early warning systems in Ethiopia national level. ${ }^{111}$ Other approaches to flood control are to develop networks of surface water reservoirs that help moderate variations in stream flow and to increase in-field infiltration of water by terracing or building small basins or pits within fields (such as in traditional zai pits). Methods that decrease surface runoff not only help to reduce flood risks but also provide a means to better harvest rainwater in dry years, thus providing an important source of soil moisture.

- Increasing irrigation Irrigated lands can produce much higher crop yields than rain-fed lands because they are less susceptible to droughts and floods. ${ }^{112}$ According to the New Partnership for Africa's Development (NEPAD), only $7 \%$ of arable land in Africa is irrigated, with the number being around $3.7 \%$ in Sub-Saharan Africa. ${ }^{113}$ The current costs of irrigation can be high; the World Bank estimates that in the Zambezi basin, the costs of tripling the irrigated area are equal to the benefits. ${ }^{114}$

111 Ethiopia NAPA, supra, note 110, at 9.

112 Aziz Bouzaher from the World Bank estimates that the yields could be three to four times higher with irrigated lands compared to rain-fed lands in Zambezi. See Aziz Bouzaher et al., "Is Climate Change a Threat or an Opportunity for Africa?", 20th Anniversary Conference of the African Economic Research Consortium, at 26, 15-17 September 2008.

113 See NEPAD, "Comprehensive Africa Agriculture Development Programme: Process and Scope of the Agriculture Programme", at 2, July 2003, available on the Internet at <http://www.nepad.org/system/files/caadp.pdfis (last accessed on 25 July 2013).

114 See Aziz Bouzaher and Shanta Devarajan, "Climate Change: Africa's Development Opportunity", Energy-Climate Change Technology (ETC) Conference, Bergen, at 16, 23-24 September 2009. 
However, when the impacts of climate change are included in the analysis, the benefits double. Therefore, given current drought conditions in the Sahel and projected increases in rainfall intensity and temperature, it may be prudent in terms of financial costs and adaptation benefits for the UNFCCC to encourage projects that emphasize increasing irrigation. Reservoirs can help avoid flooding during times of heavy rainfall, and moist soil can help manage the impact on crops of increased temperature.

Some of the examples above could also involve cross-country collaboration, such as in development of early warning systems or irrigation infrastructure and management systems.

An example of the second project type (collaborative projects that emphasize technology transfer across geographic regions) is:

- Crop breeding and the conservation of crop genetic resources

African farmers have long adapted crops to local climate conditions, but the climate is changing so rapidly, especially in regards to temperature, that traditional methods of adaptation will likely be inadequate. A 2009 study indicates that by 2030 , "growing season average temperature will be hotter than any year in historical experience for 4 years out of 10 for the majority of African maize area" and by 2050, for 9 years out of $10 .^{115}$ One way to quickly advance crop breeding for anticipated high temperatures is to encourage conservation of crop genetic resources in countries that currently exhibit the climate that other countries will experience in the future - and to share those crop breeds. The 2009 study found that fourteen countries in Africa have current climates in their own countries that coincide less than $50 \%$ with future climates in their own countries; in other words, over $50 \%$ of the time, areas of these countries will experience future climate conditions that are unprecedented within the individual countries. However, these same fourteen countries have five or more countries with current cli-

\footnotetext{
115 Marshall B. Burke et al., "Shifts in African Crop Estimates by 2050, and the Implications for Crop Improvement and Genetic Resources Conservation", 19 Global Environmental Change (2009), at 317, 320.

$116 \mathrm{lbid}$. at 323 (emphasis added).

117 UNFCCC, supra, note 2, at Art. 4(1).
}

mates that coincide at least $75 \%$ with the fourteen countries' predicted future climates. ${ }^{116}$ The UNFCCC's encouragement of these types of adaptation projects would go a long way in making good use of state-of-the-art climate forecasts and research as well as in helping countries prepare for current and future climate changes.

The UNFCCC - likely in consultation with the GEF, STAP, Adaptation Fund Board, World Bank (as interim trustee of the Green Climate Fund), and the MDBs and UN organizations that serve as the biggest implementing entities for the UNFCCC funds - is in the best position to evaluate what changes would need to be made to UNFCCC language and what guidelines and requirements would need to be adopted at the COPs in order to effectuate the above recommendations. Nonetheless, we provide suggestions here in order to clarify how our recommendations could be implemented.

The text of the UNFCCC convention provides a very basic framework for the rights and responsibilities of adaptation funding and already encompasses the recommendations we make above. The most applicable provision in this instance is Article 4(1):

All Parties, taking into account their common but differentiated responsibilities and their specific national and regional development priorities, objectives and circumstances, shall ... (e) Cooperate in preparing for adaptation to the impacts of climate change; develop and elaborate appropriate and integrated plans for coastal zone management, water resources and agriculture, and for the protection and rehabilitation of areas, particularly in Africa, affected by drought and desertification, as well as floods ... 117

This language allows for COP decisions that articulate guidelines for the UNFCCC funds on prioritizing the two types of projects discussed above. However, there is room for clarity in the Article 4(1) language. Subsection e could include a provision that all parties shall strive to use the most current and accurate climate forecasts in assessing adaptation needs and planning adaptation projects. Going further, subsection e could require that all parties shall encourage adaptation projects that address risks that are increasing relative to historical observations and collaborative projects that emphasize technology transfer across geographic regions. 
Although the UNFCCC language could be more specific in its requirements of parties, the more appropriate mode of clarification is through the COP decisions, as this is where details are layered onto the basic UNFCCC framework. It is also easier and faster to adopt new COP decisions (thereby allowing swifter use of new information) than it is to modify the language of the UNFCCC itself. Most provisions of COP decisions articulate the mechanics of fund operation and management or provide very general guidelines about the substantive priorities of the funds (e.g., the fund should focus on adaptation and the needs of developing countries). ${ }^{118}$ Some decisions include more detail and could be bolstered by future COP decisions that include language effectuating our recommendations above. For example, Decision 5/CP.9 requires that implementation of adaptation activities through the SCCF must include activities where sufficient information is available to warrant such activities, that monitor diseases and vectors affected by climate change, that support capacity-building for disaster preparedness and management, and that strengthen information networks for rapid response to extreme weather events. ${ }^{19}$ A future COP decision could expand upon this SCCF mandate by requiring that adaptation activities emphasize risks that are increasing from historical levels and emphasize technology transfer across geographic regions.

The most detailed guidelines for the UNFCCC adaptation funds are included in the Annex to Decision 28/CP.7, which provides the framework for the preparation of NAPAs. There are many parts of the Annex that could be expanded to reflect our recommendations. For example, the Annex describes how the LDCs' high vulnerability and low capacity require an emphasis in the NAPAs on urgent and immediate needs. ${ }^{120}$ As this article explains, however, there are ways to acknowledge this reality while also engaging in projects that prepare people in developing countries for the impacts of longterm climate change. For example, here is the language for one provision in the Annex: "The rationale for developing NAPAs rests on the low adaptive capacity of LDCs, which renders them in need of immediate and urgent support to start adapting to current and projected adverse effects of climate change. Activities proposed through NAPAs would be those whose further delay could increase vulnerability, or lead to increased costs at a later stage..121
Language such as the following could be added to create a mandate that is more reflective of the differences between climate variability and climate change: "In evaluating vulnerability and the costs of responding to climate-related impacts, project planners and funding entities should give heightened consideration to risks that are expected to increase over time due to climate change and should prioritize projects that tackle climate change in addition to variability." Similar language could be included in sections of the Annex that describe the objective, characteristics, guiding elements, and process of NAPAs. ${ }^{122}$

To provide further support for our two proposed types of projects, we also recommend that the implementation of the Green Climate Fund take into account the above discussion about the differences between climate variability and climate change and the resulting impact on adaptation. While it is impossible and unnecessary to reject projects that address climate variability, all efforts should be made to encourage projects that recognize the particular impacts of climate change and take steps to adapt to the projected impacts. Similarly, the Green Climate Fund should support interstate projects that are best able to take advantage of climate change forecasts and might be supported with the pooled resources to undertake research and technology sharing that is beneficial on a large scale.

\footnotetext{
118 See, e.g., Decision 5/CP.6, supra, note 30; Decision 7/CP. 7, Funding under the Convention, UN Doc. FCCC/CP/2001/13/Add.1, 21 January 2002.

119 See Decision 5/CP.9, at para. 2, Further Guidance to an Entity Entrusted with the Operation of the Financial Mechanism of the Convention, for the Operation of the Special Climate Change Fund, UN Doc. FCCC/CP/2003/6/Add.1, 22 April 2004). For provisions that could similarly be revised, see Decision 1/CP.6, supra, note 26, at Box A; Decision 1/CP.12, at paras. 1 and 2, Further Guidance to an Entity Entrusted with the Operation of the Financial Mechanism of the Convention, for the Operation of the Special Climate Change Fund, UN Doc. FCCC/CP/2006/5/Add.1, 26 January 2007.
}

120 See Decision 28/CP.7, supra, note 59, at Annex paras. 1 and 2. $121 \mathrm{lbid}$. at Annex para. 2.

$122 \mathrm{lbid}$. at Annex paras. 5-8. 


\section{Conclusion}

The funding sources described above represent only a slice of the money and resources available to developing countries as they adapt to climate change, and similarly, the observations at COP16 and $\mathrm{COP}_{17}$ as well as the review of Ethiopia's SCCF project provide only a glimpse into the climate change adaptation discussions and projects happening around the world. While this article is only a survey of these resources and of the extensive scientific research being conducted relating to climate change, it serves to provide a broad view of the climate change adaptation landscape. What we see is that most recent adaptation projects prepare for the world of 2020, not the world expected in 2050. The emphasis on adaptation to climate variability is pervasive, and while such action may help countries prepare for long-term climate change better than no action at all, it is often missing important aspects of climate change that will significantly impact agriculture, economic health, and quality of life in developing countries.

The most outstanding omissions from many adaptation programs and projects appear to be a discussion of rising temperatures and rainfall intensity. There is no doubt that drought is a critical constraint on Sahelian agriculture and will likely remain so for the foreseeable future. However, drought does not exist everywhere in every year, and in some regions such as the Eastern Sahel, it may even become less important in the future. Dealing with climate risks other than drought, namely heat waves and heavy rainfall, will become increasingly important with climate change, and investment portfolios for climate adaptation should recognize this fact.

Many resources reviewed for this report argue that countries in the Sahel must cope with current climate variability first and foremost, given the extremely urgent immediate needs in these countries. In addition, the resources highlight the weakness of climate models and forecasts to accurately characterize climate change at small scales. Both are indeed good reasons to focus on climate variability rather than change. Yet true adaptation to climate change will require dealing with risks such as extreme heat and heavy rainfall. Although these risks may be less relevant than drought in today's climate, they will become increasingly important over the next few decades.

The development of the Green Climate Fund provides an excellent opportunity to review the current funding structure for climate change adaptation and correct some of the shortcomings by taking into account the above discussion about the differences between climate variability and climate change and the resulting impact on adaptation. 